\title{
KOMPARASI HAM DALAM PERSPEKTIF ISLAM DAN INTERNASIONAL
}

\author{
Sahlani \\ Sahlaros44@yahoo.com \\ (Dosen Fakultas Agama Islam Universitas Muhammadiyah Tangerang).
}

\begin{abstract}
Abstrak:
Al-Qur'an sebagai sumber hukum Islam memberikan penghargaan yang tinggi terhadap hak asasi manusia. Dalam hadits Nabi SAW bersabda dalam khutbah haji Wada': Sesungguhnya darah kalian, harta-harta kalian, dan kehormatan-kehormatan kalian itu haram/mulia-dilindungi atas kalian seperti haramnya/mulianya-dilindunginya hari kalian ini di bulan kalian ini di negeri kalian ini. (Shahih Al-Bukhari no 105, dan Shahih Muslim no 1218). Piagam Madinah terdiri dari 47 pasal. Prinsip-prinsip hak asasi manusia dalam Piagam Madinah adalah: 1), interaksi secara baik dengan sesama, baik pemeluk islam maupun non muslim. 2), saling membantu dalam menghadapi musuh bersama. 3), membela mereka yang teraniaya. 4), saling menasehati. Kelima 5), menghormati kebebasan beragama. Hal ini dilakukan demi nilai tertinggi yang dapat digapai oleh manusia yang menopang dirinya kepada tingginya peradaban.
\end{abstract}

\section{Kata kunci: HAM, Islam, Internasional.}

\section{A. Pendahuluan}

Islam adalah agama rahmatal lil'alamin, manusia sebagai makhluk mulia tidak selalu mampu mengimplementasikan nilai luhur yang diketahui, baik dari agama yang bersumber dari wahyu atau pun berasal dari logika yang mendeteksi nilai mulia. Ego seseorang yang diliputi oleh nafsu menggerakkan orang untuk melakukan tindakan yang merugikan. Masyarakat dunia telah berupaya untuk melahirkan norma-norma yang dapat memagari keberlangsungan perdamaian dan anti penindasan. Jauh sebelumnya Islam telah mengajarkan norma-norma bahkan jauh lebih rinci dan lebih kokoh.

Hak Asasi Manusia (HAM) dalam perspektif syariah dan Deklarasi Internasional memiliki kesamaan dan perbedaan. Persamaannya, keduanya adalah pengontrol dan ukuran nilai dan keduanya merupakan konsep. Masingmasing memiliki tujuan yang sama yaitu kemaslahatan manusia agar hidup aman, bahagia dan jauh dari pengerusakan. Perbedaan keduanya HAM dalam perspektif Deklarasi Internasional lebih diterima oleh masyarakat internasional karena dianggap lebih akomodatif dan terlepas dari subjektifitas keagamaan. Sebaliknya dalam perspektif syariah hanya diakui oleh umat Islam, meskipun secara substansial HAM dalam perspektif syariah lebih detail dan rinci cakupannya dibandingkan dengan HAM dalam perspektif PBB. Seperti diketahui, artikel 1 sampai dengan 29 piagam $\mathrm{PBB}$ tentang HAM telah merekomendasikan untuk mempromosikan dan memperjuangkan hak-hak asasi dan kebebasan bagi seluruh umat manusia, tanpa membedakan ras, jenis kelamin, bahasa maupun agama. ${ }^{1}$ Hak

\footnotetext{
${ }^{1}$ United Nations, "The Universal Declaration of Human Rights", dalam Microsoft Encarta 2006. Microsoft Corporation. All Rights Reserved, 19932005.
} 
Asasi Manusia internasional jika dilihat dalam perspektif sejarah, secara kelembagaan itu muncul dalam kehidupan manusia sejak tahun $1215 \mathrm{M}$ dengan Piagam Magna Charta di Inggris yang isinya membatasi kekuasaan raja.

Masalah Hak Asasi Manusia, merupakan masalah yang tidak ada habisnya dan menarik untuk dibicarakan hingga sekarang. Di satu sisi pendeklarasian HAM layak untuk ditampilkan agar tidak lagi terjadi diskirminasi baik secara fisik maupun psikis kepada orang lain. Namun di sisi lain, HAM dijadikan tameng untuk melanggar hak asasi itu sendiri.

\section{B. Pembahasan}

\section{Ayat-ayat Al-Qur'an yang Menunjukkan adanya HAM}

a. Dalam Al-Qur'an terdapat 80 ayat tentang hidup, pemeliharaan hidup dan penyediaan sarana kehidupan, misal salah satunya dalam QS. Al-Maidah[5]: 32.

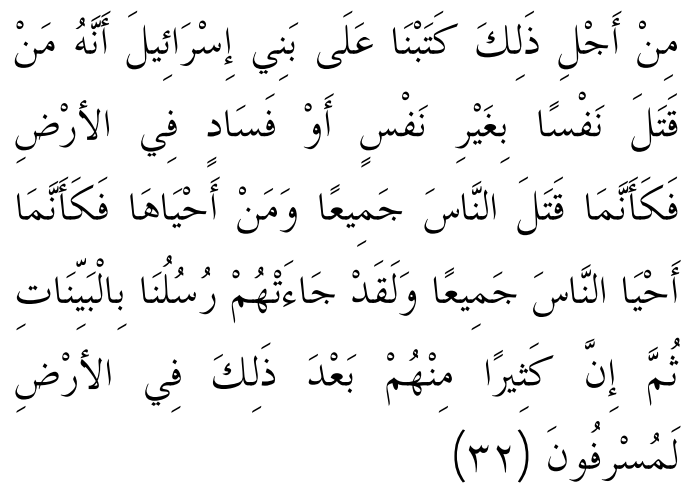

Oleh karena itu, Kami tetapkan (suatu hukum) bagi Bani Israil bahwa barang siapa membunuh seseorang, bukan karena orang itu membunuh orang lain, atau bukan karena berbuat kerusakan di bumi, maka seakan-akan dia telah membunuh semua manusia. Barang siapa memelihara kehidupan seorang manusia, maka seakan-akan dia telah memelihara kehidupan semua manusia. Sesungguhnya rasul Kami telah datang kepada mereka dengan (membawa) keterangan-keterangan yang jelas. Tetapi kemudian banyak di antara mereka setelah itu melampaui batas di bumi. (QS. Al-Maidah[5]: 32. ${ }^{2}$

b. Al-Qur'an juga menjelaskan 150 ayat tentang ciptaan dan makhluk-makhluk serta tentang persamaan dalam penciptaan, misal salah satunya dalam QS. Al-Hujarat [49] :13.

c. Al-Qur'an telah mengetengahkan sikap menentang kezaliman dan orang-orang yang berbuat zalim dalam sekitar 320 ayat dan memerintahkan berbuat adil dalam 50 ayat yang diungkapkan dengan kata: adl, qisth dan qishsh.

d. Dalam Al-Qur'an terdapat sekitar 10 ayat yang berbicara mengenai larangan memaksa untuk menjamin kebebasan berfikir, berkeyakinan dan mengutarakan aspirasi, misal salah satunya yang ditemukan dalam QS. AlKahfi[18]: 29.

e. Ayat-ayat lain yang menunjukkan penghormatan HAM dalam ajaran Islam antara lain: Hak Persamaan dan Kebebasan (QS. Al-Isra: 70, An Nisa: 58, 105, 107, 135 dan Al-Mumahanah: 8). Hak Hidup (QS. Al-Maidah: 45 dan Al - Isra: 33). Hak Perlindungan Diri (QS. al-Balad: 12 - 17, At-Taubah: 6). Hak Kehormatan Pribadi (QS. AtTaubah: 6). Hak Keluarga (QS. AlBaqarah: 221, Al-Rum: 21, An-Nisa 1, At-Tahrim: 6). Hak Keseteraan Wanita dan Pria (QS. Al-Baqarah: 228 dan AlHujrat: 13). Hak Anak dari Orangtua (QS. Al-Baqarah: 233 dan surah AlIsra: 23 - 24). Hak Mendapatkan Pendidikan (QS. At-Taubah: 122, Al-

${ }^{2}$ Terjemahan al-Qur' an QS al-Maidah (5): 32 ini diambil dari Departemen Agama, Al-Qur'an dan Terjemahnya, Saudi Arabia, Fahd Publisher, 2003, HIm. 34. 
Alaq: 1 - 5). Hak Kebebasan Beragama (QS. Al-kafirun: 1 - 6, Al-Baqarah: 136 dan Al Kahti: 29). Hak Kebebasan Mencari Suaka (QS. An-Nisa : 97, Al Mumtaharoh: 9). Hak Memperoleh Pekerjaan (QS. At-Taubah: 105, AlBaqarah: 286, Al-Mulk: 15). Hak Memperoleh Perlakuan yang Sama (QS. Al-Baqarah 275 - 278, An-Nisa 161, Al-Imran: 130). Hak Kepemilikan (QS. Al-Baqarah: 29, An-Nisa: 29). Dan Hak Tahanan (QS. AlMumtahanah : 8).

\section{Hadits yang Menunjukkan Adanya HAM:}

Hak asasi manusia (HAM) dalam kitab-kitab hadits shahih, hasan, dan musnad-musnad, tidak hanya satu bentuk, di antaranya bahwa Nabi SAW bersabda dalam khutbah haji Wada':

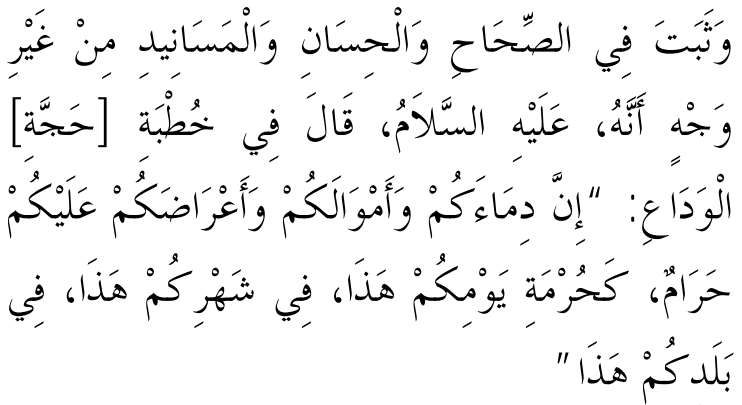

Telah tetap (keshahihannya) dalam kitabkitab shahih, hasan, dan musnad-musnad, tidak hanya satu bentuk, bahwasanya Nabi shallallahu 'alaihi wa sallam bersabda dalam khutbah haji Wada': Sesungguhnya darah kalian, harta-harta kalian, dan kehormatan-kehormatan kalian itu haram/mulia-dilindungi atas kalian seperti haramnya/mulianya-dilindunginya hari kalian ini di bulan kalian ini di negeri kalian ini. ${ }^{3}$

${ }^{3}$ Bukhari, Shahîh al-Bukhârî no.105: Kitâb al-Janâiz, Kairo, Dâr al-Hadîts, t.t. jilid II, hlm. 345; Muslim, Shahîh Muslim no. 1218: Kitâb alQadr, Dâr al-Hadîts, t.t., jilid IV, hlm. 351. $\begin{array}{ccc}\text { Dalam } & \text { sebuah hadis yang } \\ \text { diriwayatkan } & \text { oleh } & \text { Ibnu Abbas }\end{array}$ radhiyallahu 'anhu, Rasulullah shallallahu 'alaihi wasallam bersabda;

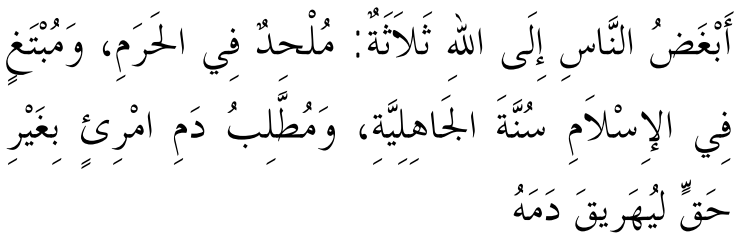

Manusia yang paling dimurkai Allah adalah tiga golongan; Orang yang melakukan pelanggaran di tanah haram, orang yang mencari-cari tradisi jahiliyah padahal telah masuk Islam, dan orang yang berupaya untuk menumpahkan darah seseorang tanpa alasan yang dibenarkan.” (HR. Bukhari)

\section{Pengertian Hak Asasi Manusia (HAM)}

Dalam kamus bahasa Inggris "hak" diartikan dengan "right" dengan berbagai makna: the right solution, yakni sesuatu yang benar; a right time, yakni sesuatu yang lurus; is the right man for the job, yakni sesuatu yang cocok atau sesuai. ${ }^{4}$ Kata hak yang dipergunakan dalam bahasa sehari-hari, berasal dari bahasa Arab "Haq" yang terbentuk dari huruf $ح$ dan dengan makna dasar yang berarti mengerjakan sesuatu dengan sempurna dan benar. ${ }^{5}$ Analisis morfologis "haq" adalah dengan makna etimologi sesuatu yang benar, nyata, pasti, tetap. Dapat juga يحق عليكك ا ن تفعل كذا : "wajib bagi kamu melakukan yang begini”.

${ }^{4}$ Munir Ba'al Al-Bahi, al-Mawrid A Modern English-Arabic Dictionary. Baerut: Dar al-Ilm li alMalayin, 1979), hlm. 798.

${ }^{5}$ Ibn Faris Abi al-Husain Ahmad ibn Zakariyah, Mu'jam al-Maqayis al-Lugat, Juz II. (Cet. I; Baerut Dar al-Fikr, 1962), hlm. 15. 
Diartikan pula sebagai justifikasi dalam melakukan sesuatu. ${ }^{6}$

Lafal asasi, berakar kata yang terdiri dari huruf 1 dan mempunyai makna pokok "sesuatu yang tetap" dan "sesuatu yang kekal”. Diartikan pula sebagai "bangunan dasar"" Bentuk plural dari اس adalah ساس I. Di dalam Kamus Besar Bahasa Indonesia, hak asasi diartikan sebagai hak dasar atau hak pokok seperti hak hidup dan hak mendapatkan perlindungan. $^{8}$ Hak-hak Asasi Manusia adalah hak-hak yang dimiliki manusia menurut kodratnya, yang tak dapat dipisahkan dari pada hakekatnya dan kaena itu bersifat suci. ${ }^{9}$

Prinsip-prinsip umum tentang hakhak asasi manusia yang dicanangkan Majelis Umum Perserikatan BangsaBangsa (PBB) pada tahun 1948 dianggap sebagai pedoman standar bagi pelaksanaan penegakan HAM bagi bangsa-bangsa, terutama yang bergabung dalam badan tertinggi dunia itu hingga saat ini. Prinsipprinsip umum tersebut dikenal dengan Universal Declaration of Human Rights, UDHR (Pernyataan Semesta tentang Hakhak Asasi Manusia). Dinyatakan pula bahwa deklarasi tersebut bukanlah sebuah dokumen yang secara sah mengikat, dan beberapa ketentuannya menyimpang dari peraturan-peraturan yang ada dan diterima secara umum. Walaupun demikian, beberapa ketentuannya mengatur prinsip-

${ }^{6}$ Ibrahim Anis,et al. al-Mu'jam al-Wasit, Juz I (Cet. I; Baerut: Dar al-Fikr, 1985), hlm. 1815.

${ }^{7}$ Ibn Faris Abi al-Husain Ahmad ibn Zakariyah, Mu'jam al-Maqayis al-Lugat, Juz II., hlm. 37.

${ }^{8}$ Tim Penyusun Kamus Departemen Pendidikan dan Kebudayaan R.I., Kamus Besar Bahasa Indonesia, (Jakarta: t.p, 1988), hlm. 292.

${ }^{9}$ Ian Brownlie, Dokumen-dokumen Pokok Mengenai Hak Asasi Manusia, (Jakarta: UI Press 1993), hlm. 26 prinsip umum hukum atau menggambarkan pandangan pokok tentang perikemanusiaan.Dalam kapasitasnya, deklarasi tersebut secara tidak langsung benar-benar sah, dan dianggap oleh Majelis Umum dan beberapa ahli hukum sebagai bagian dari undang-undang perserikatan bangsa-bangsa. ${ }^{10}$

\section{HAM; Sejarah dan Eksistensinya a. Sejarah Singkat Kelembagaan HAM}

Secara nilai hak asasi manusia dimiliki oleh semua individu bahkan sejak penciptaan manusia pertama. Apabila menoleh ke sejarah, maka akan didapati bahwa jauh sebelum Barat mendeklarasikannya, hak-hak asasi tersebut telah termaktub dalam aturan resmi "Negara Madinah" yang dipimpin oleh Rasulullah saw dan biasa diistilahkan dengan Piagam Madinah. Yang paling menakjubkan, bahwa piagam tersebut merupakan dokumen resmi pertama kali dalam sejarah mengandung prinsip dan kaedah kenegaraan serta nilai-nilai kemanusiaan yang sebelumnya belum dikenal oleh umat manusia. ${ }^{11}$ Namun secara kelembagaan, embrionya muncul sejak tahun 1215 diatas dalam Piagam Magna Charta, hingga lahirlah Petition of Rights tahun 1627, kemudian berkembang hingga tahun 1628 pada negara yang sama muncul "Bill of Rights" yang menegaskan bahwa manusia adalah sama dihadapan hukum (equality before the Law).

Di Perancis, Rousso dengan Kontrak Sosial (Social Contract) dan Montesque dengan Trias Politikanya (Legislatif, eksekutif dan yudikatif) telah menyuarakan

\footnotetext{
${ }^{10}$ Ian Brownlie, hlm.. 26

${ }^{11}$ Nurcholish Madjid, "Agama dan Negara dalam Islam: Telaah atas Fiqh Siyasi Sunni" dalam Budhy Munawar Rachman (ed.), Kontekstualisasi Doktrin Islam Dalam Sejarah (Cet. II; Jakarta: Temprint, 1995), hlm. 590.
} 
inti-inti makna hak asasi manusia. Tahun 1787 di negara ini juga lahir "The French Declaration" yang melahirkan statemenstatemen berikut:

1) Larangan penangkapan sewenangwenang

2) Pentingnya praduga tak bersalah (Presumtion of Innocent)

3) Kebebasan berekspresi (Freedom of expression)

4) Kebebasan beragama (Freedom of religion)

5) Perlindungan hak milik (the right of Property).

Di Tiongkok kita mengenal Min Tsu, Min chuang, dan min seng, yang berarti kemerdekaan, persamaan, dan persaudaraan. Pada pasca perang dunia kedua, Presiden Amerika Serikat "Rosevelt" menyatakan statemennya yang dikenal dengan "Four Freedom (Empat Kebebasan):

1) Bebas berpendapat dan berekspresi (Freedom of speech and expression)

2) Bebas dari ketakutan (Freedom from fear)

3) Bebas dari kekurangan (Freedom from want)

4) Bebas beragama (Freedom of religion)

Pernyataan inilah menurut sejarah sebagai cikal bakal lahirnya Deklarasi Universal tentang Hak Asasi Manusia (The universal declaration of human rights) di PBB pada tanggal 10 Desember 1948. Deklarasi ini menyatakan:

1) Hak untuk hidup

2) Kemerdekaan dan keamanan badan

3) Hak untuk diakui kepribadiannya menurut hukum

4) Hak untuk memperoleh perlakuan yang sama dengan orang lain menurut hukum

5) Hak untuk mendapat jaminan hokum dalam perkara pidana seperti diperiksa di muka umum, dianggap tidak bersalah kecuali ada bukti yang sah

6) Hak untuk masuk dan keluar wilayah suatu negara

7) Hak untuk mendapat hak milik atas benda

8) Hak untuk bebas untuk mengutarakan pikiran dan perasaan

9) Hak untuk bebas memeluk agama serta mempunyai dan mengeluarkan pendapat

10) Hak untuk berapat dan berkumpul

11) Hak untuk medapatkan jaminan sosial

12) Hak untuk mendapatkan pekerjaan

13) Hak untuk berdagang

14) Hak untuk mendapatkan pendidikan

15) Hak untuk turut serta dalam gerakan kebudayaan dalam masyarakat

16) Hak untuk menikmati kesenian dan turut serta dalam kemajuan keilmuan.

b. Eksistensi Hak Asasi Manusia (HAM) Internasional

Secara idealisme, kita memandang positif eksistensi HAM Internasional, sebab hal itu mengandung unsur kebajikan pembawa kemaslahatan. Siapa pun yang mempromosikan HAM layak untuk didukung. Namun praktiknya seringkali HAM dijadikan standar normatif dan barat sebagai pengontrolnya dan keuniversalan HAM internasional tidak selalu layak menembus budaya lokal. Hingga dari sini tampak pemakasaan nilai yang secara tidak langsung merupakan bentuk penjajahan moral dan budaya. Selain itu HAM terkadang digunakan sebagai retorika untuk menutupi standar ganda dalam kebijakan politik dan ekonomi barat. Selain itu sering kita menjumpai adanya penyetopan bantuan luar negeri dan pemblokiran perdagangan dunia yang dihubungkan dengan pelanggaran HAM. Inilah faktor penyebab beratnya dunia ketiga termasuk dunia Islam untuk mengakui keabsahan HAM internasional. 
Disamping Islam juga memiliki formula yang khas tentang Hak Asasi Manusia (HAM);

\section{Hak Asasi Manusia (HAM) dan Syariah}

Ada satu pertanyaan penting terkait dengan tema bahasan kali ini: Mengapa masalah HAM tidak terbahas secara khusus dalam Islam sejak seribu tahun lebih dari zaman kerasulan.? Mengapa baru abad sekarang-sekarang ini ramai dibicarakan permasalahan HAM dalam masyarakat muslim.? Kedua pertanyaan diatas secara tidak langsung menunjukkan terjadinya perubahan tatanan sosial yang baru. HAM dalam perspektif internasional jika dibicaraka dari sisi idealisme lebih simpel jikan dibandingkan dengan Islam. Pembahasan HAM dan pembentukan lembaga terkait dalam kontek dan konsumsi internal menunjukkan penurunan dan kemunduran dalam memandang islam sebagai way of life. Kedewasaan dan kematangan umat Islam dalam hal ini perlu dipertanyakan. Sebab sangat jelas, tidak adanya pembahasan HAM secara khusus dalam kurun yang cukup lama menunjukkan kemapanan umat dalam memahami makna agama, menghayati, dan mengamalkan tanpa ada lembaga pengontrol selain agama. Namun kaitannya ke eksternal, pembahasan HAM mengandung unsur positif. Paling tidak memperluas wawasan dalam kancah pluralitas umat yang kian memesat guna mengkaunter problematika global bahwa Islam memiliki formula yang khas.

Hak asasi manusia memiliki sifat yang legal, artinya hak-hak itu tidak bergantung kepada adanya suatu negara atau undang-undang dasar, lepas dari pemerintah yang tengah berkuasa. ${ }^{12}$ Korelasi antara HAM Internasional dan syariah adalah juz' (bagian) dengan kull (keseluruhan). Cakupan yang dimilki syariah melebihi HAM. Sangat jauh sebetulnya bandingan antara Yang Kuasa dengan manusia. Abdul Qadir telah mengatakan dalam bukunya "At Tasyri' al Jina'i al Islamiy": "Syariat tidak bisa disetarakan dengan hukum wadh'i (buatan manusia) dan tak benar mengkiyaskan syariah dengan hukum tersebut. Sebab tabiat keduanya jauh berbeda." ${ }^{13}$ Permasalahannya sekarang cuma syariah diakui dan dijalani oleh umat Islam saja, meskipun secara nilai tak sedikit dari non muslim mengakui keberadaannya. Itu pun tak seluruhnya diimplementasikan oleh umat Islam itu sendiri. Bahkan tak sedikit dari kalangan umat Islam mengetahui HAM internasional lebih banyak dari syariah. Fenomena seperti itulah yang menyebabkan pihak Islam mengikuti aturan permainan HAM ala PBB. Jadi masalahnya subjek bukan objek Pola hubungan antara umat Islam dengan HAM internasional disatu pihak menolak untuk bersahabat. Sebab keberadaannya bahkan segala jenis sekutunya seperti Amnesty Internasional dianggap tidak melahirkan kontribusi positif, bahkan sebaliknya hanya pengrusakan. Kelompok seperti ini bisa terwakili dengan Ayatullah Khomaini. Tahun 1981 beliau berkata: "Hati-hatilah! Segala unsur kekuatan setan dan sekutunya seperti Amnesty Internasional dan organisasi lain telah bersatu untuk menghancurkan Republik Islam kita ini

\footnotetext{
${ }^{12}$ H.A.R. Tilaar, Dimensi-Dimensi Hak Asasi Manusia dalam Kurikulum Persekolahan Indonesia (Bandung: P.T. Alumni, 2001), hlm. 21.

${ }^{13}$ Abdul Qadir Audah, At Tasyri al Jina'i al Islamiy, Muaassasah ar risalah, 1994
} 
dan tak mengizinkannya untuk berkembang. Kita tahu bahwa Amnesty Internasional yang minta izin untuk datang ke Iran dan memerikasa apa yang sedang terjadi disini sebenarnya membawa misi untuk datang dan mengecam negara kita. Mereka bersatu untuk menghancurkan gerakan Islam kita ini, yang tidak lain berarti menghancurkan Islam. Mereka takut dengan Islam dari awalnya memang mereka takut. Tapi sekarang mereka seakan tertampar mukanya oleh Islam. Ketakutan mereka pun semakin menjadijadi." ${ }^{14}$ Dilain pihak ada segolongan yang mencoba menafsirkan HAM internasional dengan tafsiran yang moderat dan mengusakan adanya keharmonisan antara syariah dan HAM Internasional. Kemudian memperjuangkan keharmonisan itu untuk tetap eksis. Yang bisa dikatagorikan dalam kelompok ini misalnya Profesor Abdullah Ahmad An Naim, aktivis HAM di Sudan yang mendapat reputasi internasional dalam pembelaannya terhadap HAM. Lebih lanjut dia menyatakan harus diadakan tafsir baru terhadap Al Qur'an yang bisa meredam ketegangan antara HAM internasional dan syariah.

Sebagai pelajar sekaligus sebagai bagian dari komunitas muslim, dalam melihat fenomena aktifitas HAM internasional tidak ada salahnya memandang sebagaimana kelompok kedua. Selama nilai-nilai HAM internasional tidak merusak norma-norma agama dan tidak disalahguanakan. Sebab selain sejalan dengan ajaran agama, kondisi seperti itu juga mengandung nilai plus dalam berinteraksi dengan negara lain. Apalagi di era globalisasi ini ketergantungan antara satu negara dengan yang lain sangat tinggi. Namun jika apa yang dikatakan oleh Ayatullah Khumaini itu benar, mengapa tidak bersikap sebagaimana beliau bersikap.

\section{Komparasi HAM dalam Perspektif Islam dan Internasional}

Bahwa muatan HAM yang terkandung dalam Syariah jauh lebih sempurna dari HAM internasional. Untuk lebih kongkrit bukti-bukti dibawah ini dapat dijadikan landasan keotentikannya.

a. Hak-hak yang termaktub dalam Al Qur'an dan Deklarasi PBB

1) Hak persaudaraan, kerjasama, dan persamaan antar semua golongan.(QS. Ali Imran: 103). (QS. Al-Maidah: 2)

2) Hak untuk hidup, kebebasan dan kemanusiaan. (QS. An Nisa: 92)

3) Hak bebas dari perbudakan. (QS. An Nisa: 92)

4) Hak muamalah yang baik, bebas dari paksaan dan aniaya. (QS. At Taubah: 6)

5) Hak dalam hukum dan peradilan.(QS. An Nisa: 58)

6) Hak pengakuan terhadap rahasia dalam hidup dan kekhususan individu. (QS. Al Hujurat: 12)

7) Hak kebebasan berpergian, pindah dan singgah. (QS. Al Ankabut: 56)

8) Hak melakukan pernikahan dan berkeluarga.(QS. An Nahl: 72)

9) Hak kepemilikan harta. (QS. An Nisa: 29)

10) Hak menganut pemikiran, bermasyarakat, dan beraqidah. (QS. Al Baqarah: 256)

11) Hak bebas mengadakan perkumpulan dan membentuk badan-badan.(QS. Ali Imran: 103)

12) Hak berserikat dalam hukum dan pekerjaan. (QS. As Syura: 38)

${ }^{14}$ Jurnal Islamika, Ibid 
13) Hak ketentraman sosial dan perekonomian. (QS. Al A'raf: 32)

14) Hak seorang ibu dan anak kecil. (QS. Luqman: 14)

15) Hak dalam pengajaran dan budaya.(QS. Fathir: 8)

b. Hak-Hak yang Termaktub dalam Al Qur'an dan Tidak Termaktub dalam Deklarasi Internasional

1) Mencapai kesempurnaan akal dan penjagaan (ri'ayah). (QS. An Nisa: 5)

2) Hak anak yatim. (QS. An Nisa: 2)

3) Hak penjagaan diri. (QS. Al Anfal: 60)

4) Hak untuk mendapatkan maaf. (QS Al An'am: 54)

5) Hak dalam waris. (QS. An Nisa:7)

\section{Contoh Kasus Benturan HAM dan Syariah}

Menurut laporan Free doom house untuk tahun 2015, tidak ada negara Islam atau negara muslim yang dapat dikatagorikan "bebas (free) dari pelanggaran HAM. jika diperiksa, rekor untuk negara-negara yang menjadi anggota organisasi konfrensi islam (OKI) adalah "Tidak Bebas (Not Free (NF)) atau Setengah Bebas (Partly Free (PF). Indonesia dan Malaysia misalnya dinilai PF. ${ }^{15}$ Penilaian tersebut bisa jadi berbasis kepada persepsi yang berbeda tentang nilai pelanggaran terhadap Hak Asasi Manusia (HAM) dari berbagai pihak. Itulah ada beberapa kalangan yang menolak keuniversalitasan HAM, karena landasannya yang kerap subyektif dan adanya perbedaan budaya (Culture Based Resistence to Rights).

Berkaitan dengan masalah keislaman yang sering diangkat sebagai pelanggaran HAM oleh pihak internasional, diantaranya larangan pernikahan antara dua orang yang

\footnotetext{
${ }^{15}$ https: //freedomhouse.org/report/freedomworld/2015
}

berbeda agama, masalah pembagian harta waris, masalah hukuman, dan lain sebagainya. Satu dari sekian contoh yang kita bisa anggkat adalah masalah pembagian harta waris. Sebetulnya pembicaraan mengenai harta waris dalam persepektif syariah dan hukum internasional sangat jauh bersebrangan dan itu sulit untuk diadakan komparasi. dalam deklarasi internasional tentang HAM yang menjadi sumber hukum internasional lainnya yang ditetapkan pada tanggal 10 desember 1948 oleh majlim umum PBB tidak ada satu pasal pun dari 30 pasal tersebut yang berbicara mengenai harta waris cuma ada satu pernyataan yang ada sedikit hubngannya dengan objek ini, termaktub dalam konfrensi intenasionaldalam penghapusan segala bentik dikriminasi RAS yang dikeluarkan oleh majlis umum PBB tanggal 25 november 1963. Itupun sangat global dan tertulis pada ranting pasal 5.D. (IV), berbunyi "Hak untuk mewarisi (the right to inherit). Berbeda dengan Islam, persoalan dikupas secara detail sehingga tidak ada problematika pembaguan harta waris yang tidak terjawab. hal itu dapat terbukti dalam Al Qur'an diberbagai ayat. seperti surat Al Baqarah :180, An Nisa : 7, 8, 9, 10, 11, 12 dan 176 serta surat Al Maidah :106 ditambah dengan hadits-hadits nabi dan ijtihad sahabat dan tabi'in lainnya.

Dari situlah tampak perbedaan jelas antara syariat dan hukum internasional dalam membahas harta waris. Islam menjadikan masalah pembagian harta waris dalam BAB fardhu sedangkan hukum internasional memandangnya sebagai hak bukan kewajiban. Hanya problematika harta waris yang sering menjadi konflik dari kedua sistem itu adalah dari segi akses dan prakteknya. Islam memandang jelas perbedaan kedua 
jenis kelamin dikarenakan hak dan kewajiban mereka berbeda. Sedang dalam hukum internasional tidak ada pemilahan seperti itu sehingga terjadilah benturan antara keduanya dari pijak ini kemudian masalah jenis kelamin dalam pembagian harta waris terus dihubungkan denga HAM.

Keadilan merupakan sentral obyek bahasan masing-masing syariat dan hukum internasional. Kata $a l$ - 'adl dalam Al-quran menurut Al-Baidhawi dalam Pulungan bermakna "pertengahan dan persamaan". ${ }^{16}$ Walaupun satu tujuan kemasahatan namun dalam prakteknya dalam hukum tersebut saling bertolak belakang. Bagaimana tidak, perbandingan harta waris yang diterima anak laki-laki dan perempuan dalam Islam 2:1 (baca QS. An Nisa ; 176). Sedang hukum internasional menegaskan perbandingan tersebut 1:1 tanpa membandingkan perbedaan jenis kelamin.

Siapapun megakui bahwa keadilan bukan berarti sama rata tanpa mengenal kondisi. Lebih dari itu keadilan meletakan sesuatau pada posisinya yang tepat. Satu contoh yang sering kita dengar, dalam keluarga seorang ayah dikatakan tidak adil bila ia memberikan uang samarata antara seorang kakak yang belajar di universitas dan adiknya yang belajar di SD. Aksioma seperti ini juga terdapat juga hukum waris dalam islam. Artinya memberikan bagian masing-masing sesuai dengan persinya. Laki-laki dalam kondisi tersebut mendapatkan dua kali lipatdari wanita itu bukan berarti melanggar HAM atau memandang superioritas terhadap kaum laki-laki. Sebab tuntutan anak laki-laki lebih banyak dari pada perempuan. Seorang laki-laki memiliki kewajiban

\footnotetext{
${ }^{16}$ Suyuthi Pulungan, Prinsip-Prinsip Pemerintahan dalam Piagam Madinah Ditinjau dari Pandangan Al-Qur`an, hlm. 225.
}

untuk membiayai kehidupannya sendiri, mahar, nafkah istri, nafkah anak dan nafkah kedua orang tuanya yang fakir. ${ }^{17}$ Dan wanita tidak dibebani seperti itu.

Penyamarataan harta waris laki-laki dan wanita dengan alasan bahwa QS. An Nisa: 176 tersebut ditirunkan pada masa dimana tugas mencari nafkah keluarga sepenuhnya dibebankan kepad anak lakilaki kurang beralasan. Sebab sampai sekarangpun sebagai seorang suami tetap terbebani untuk mencari nafkah untuk keluarga dan itu wajib. Sekalipun si istri kerja, pada prinsipnya itu bukan kewajiban dia. Dan itu boleh-boleh saja menurut pandangan islam, selama hal tersebut tidak bertentangan dengan ajaran islam. Jika hukum waris dirubah secara mutlak 1:1 dengan alasan membela wanita karena mereka sudan banyak mencari nafkah, itu justru menambah beban bagi wanita. Si istri dalam kondisi seperti ini telah terbebani kewajiban lain selain mengurusi urusan rumah tangga. Hal itu disebabkan karena si wanita telah terlegitimasi oelh kedudukannya yang tidak berbeda dengan pria dalam hak dan kewajiban. Bahkan sekalipun dituntun untuk terjadi perubahan. Mengapa kedudukan lainnya tidak dibahas seperti pemberian mahar, mengapa harus laki-laki yang memberi.?

Dari fenomena tersebut minimal bagi si istri telah mengurangi keterlibatannya dalam mendidik anak. Bukankan ibu adalah pendidik bagi anak. Seorang penyair berkata: ibu adalah sekolah, jika ia mempersiapkannya maka ia menyiapkan bangsa yang unggul kualitasnya. justru dengan perbandingan antara laki-laki dan perempuan 2:1 adalah motivasi bagi kedua belah pihak untuk saling melengkapi.

\footnotetext{
${ }^{17}$ Wahbah Az Zuhaily, Dr., Al-Fiqh al-Islamy wa adillatuhu, Dar al-Fikr
} 
Sebab masing-masing mempunyai keistimewaan. Jadi aturan hukum waris yang ada dalam nash benar-benar pada porsinya. Jika ditelusuri lebih mendalam lagi, tidak selamanya perbandingan itu 2:1. ini adalah bukti kongkrit bahwa islam memandang kemaslahatan. Di tempat tertentu bisa jadi perbandingan itu 1:1, sebagaimana terjadi pada ayah dan ibu yang mendapat harta waris dari anak mereka yang meninggal sedang anak tersebut mempunyai anak. Dengan demikian masing-masing kedua orang tua mendapat 1/6 (QS. ayat 11). Sebab hajat kedua orang tua dalam kondisi yang demikian sama besarnya. Begitu juga bagian saudara/i yang mewarisi harta dari saudara mereka yang tidak mempunyai ayah dan anak dalam Qur'an dikenal edngan nama Kalalah. Disini bagian saudari ibu sama dengan saudara ibu. Bahkan ada beberapa tempat dimana pihak wanita mendapat lebih dari laki-laki seperti seorang istri meninggal. Dia meninggalkan suami, ibu dua orang suadara dan saudari ibu. Maka saudari ibu mendapat 1/6 masing-masing memdapat $1 / 12$.

Kesimpulannya 2:1 itu sudah adil. ${ }^{18}$ Sebab keadilan itu memberikan sesuatu kepada anggota masyarakat sesuai dengan status, fungsi dan jasa masing-masing dalam masyarakat (Distributive Justice). Ariestoteles membedaka antara distributive justice dan corrective justice.

\footnotetext{
${ }^{18}$ Mahmud Syaltuth menyebutkan keadilan merupakan bagian yang sangat penting dalam sistem yang berorientasi kepada Tuhan. Dikatakannya, "Keadilan adalah sistem Allah SWT. dan syari'ah-Nya". Baca Mahmud Syaltut, Islam Aqidah wa Syari'ah (Cairo: Dar al-Qalam, 1966), hlm. 453.
}

8. Perbedaan Konsep Antara HAM Dalam Islam Dengan HAM Universal Declaration of Human Right

a. HAM Islam

1) Bersumber pada ajaran Al-Qur'an dan sunnah Nabi Muhammad SAW.

2) Bersifat Theocentris. Hak-hak dasar manusia sebagai anugerah yang diberikan Allah SWT.

3) Keseimbangan antara hak dan kewajiban.

4) Kepentingan sosial lebih diutamakan Karena manusia disebut makhluk sosial.

5) Manusia sebagai makhluk yang dititipi hak-hak dasar oleh Allah SWT.

b. HAM UDHR (Universal Declaration of Human Right)

1) Bersumber pada pemikiran filosofis semata. Keberhasilan dari ikhtiar tersebut dengan dikeluarkanya Deklarasi Universal Hak Asasi Manusia (Universal Declaration of Human Right) pada tahun 1948 oleh Perserikatan Bangsa Bangsa.

2) Bersifat Antrophocentris, Kedaulatan mutlak adalah milik manusia, tidak ada pihak lain yang lebih berdaulat dari manusia.

3) Lebih mementingkan hak dari pada kewajiban.

4) Lebih bersifat individualist akan memunculkan sikap egois

5) Manusia sebagai pemilik sepenuhnya hak-hak dasar.

\section{Penutup}

Al-Qur'an sebagai sumber hukum Islam memberikan penghargaan yang tinggi terhadap hak asasi manusia. Dalam al-Qura'an terdapat 80 ayat tentang hidup, pemeliharaan hidup dan penyediaan sarana kehidupan. 150 ayat tentang ciptaan dan 
makhluk-makhluk serta tentang persamaan dalam penciptaan. Terdapat 320 ayat alQur'an mengetengahkan sikap menentang kezaliman dan orang-orang zalim dan 50 ayat memerintahkan berbuat adil. Terdapat 10 ayat yang berbicara tentang larangan memaksa untuk menjamin kebebasan berfikir, berkeyakinan dan mengutarakan aspirasi. Hak asasi manusia dalam hadits diantaranya bahwasanya Nabi SAW bersabda dalam khutbah haji Wada': Sesungguhnya darah kalian, hartaharta kalian, dan kehormatan-kehormatan kalian itu haram/mulia-dilindungi atas kalian seperti haramnya/mulianyadilindunginya hari kalian ini di bulan kalian ini di negeri kalian ini. ( Shahih AlBukhari no 105, dan Shahih Muslim no 1218). Piagam Madinah terdiri dari 47 pasal. Prinsip-prinsip hak asasi manusia dalam Piagam Madinah adalah: Pertama, interaksi secara baik dengan sesame, baik pemeluk islam maupun non muslim. Kedua, saling membantu dalam menghadapi musuh bersama. Ketiga, membela mereka yang teraniaya. Keempat, saling menasehati. Dan kelima, menghormati kebebasan beragama. Hal ini dilakukan demi nilai tertinggi yang dapat digapai oleh manusia yang menopang dirinya kepada tingginya peradaban. Sebab "Islam itu tinggi dan tidak ada yang melebihi tingginya."

\section{DAFTAR PUSTAKA}

\section{Al-qur'an al-karim}

\footnotetext{
Al Alim, Yusuf Hamid, Dr., Al Maqaashid al Aammah lisy Syariah al Islamiyah, ad Daar al Islamiyyah lil kitaab al islamiy, riyadh, 1994
}

Abdul Qadir Audah, At Tasyri al Jina'i al Islamiy, Muaassasah ar risalah, 1994

Ahmad Kosasih, Ham dalam prespektif Islam, Jakarta: Salemba, 2003

Anis, Ibrahim. et al. al-Mu'jam al-Wasit, Juz I. Cet. I; Baerut: Dar al-Fikr, 1985.

Bukhari, al-T.T. Shahîh Bukhari: Kitâb alJanâiz. Kairo: Dâr al-Hadîts

Dalizar Putra, Ham menurut al-Qur'an. Jakarta: Husna zikra, 1995

Harun Nasution dan Bakhtiar Efendi (Ed), Hak-hak Asasi Manusia, Jakarta: Pustaka Firdaus, 1995

Hasbi Ash-Shiddiqi, Mutiara Hadis, Jakarta: Bulan Bintang, 1975

Ian Brownlie, Dokumen-dokumen Pokok Mengenai Hak Asasi Manusia, Jakarta: UI Press 1993

Ismail Thaib, Oksidentalis Versus Orientalis, Yogyakarta: Toko Kitab Beirut, 2011

Kuntjoro Purbopranoto, Hak-hak Asasi Manusia dan Pancasila, Jakarta: Pradya Paramita, 1982

Muhammad Ali al-Iyazi, al-Mufassirun Hayatuhum wa Manhajuhum, Teheran: t.tp 1373 _sofware Maktabah as-Syamilah v. 3.48

Muslim. T.T., Shahîh Muslim: Kitâb alQadr. Kairo: Dâr al-Hadîts.

Syaukat hussain, Hak Asasi Manusia dalam Islam, Jakarta: Gema insan press, 1996

Saiful Amin Ghofur, Profil Para Mufassir Al-Qur'an, Yogyakarta: Pustaka Insan Madani, 2008 
Pulungan, Suyuthi. Prinsip-Prinsip Pemerintahan dalam Piagam Madinah Ditinjau dari Pandangan Al-Qur`an. Jakarta; Rajawali Press, 1999.

Tilaar, H.A.R. Dimensi-Dimensi Hak Asasi Manusia dalam Kurikulum Persekolahan Indonesia. Bandung: P.T. Alumni, 2001.

Tim Penyusun Kamus Departemen Pendidikan dan Kebudayaan R.I., Kamus Besar Bahasa Indonesia, Jakarta: t.p, 1988.
United Nations, "The Universal Declaration of Human Rights", dalam Microsoft Encarta 2006. Microsoft Corporation. All rights reserved, 1993-2005.

Wahbah Az Zuhaily, Dr., Al-Fiqh alIslamy wa adillatuhu, Dar al-Fikr, Beirut, Libanon 